\title{
Mucosal Melanoma of the Head and Neck Pathologic Primary Tumor TNM Finding v7
}

National Cancer Institute

\section{Source}

National Cancer Institute. Mucosal Melanoma of the Head and Neck Pathologic Primary

Tumor TNM Finding v7. NCI Thesaurus. Code C89131.

A pathologic finding about one or more characteristics of mucosal melanoma of the head and neck, following the rules of the TNM AJCC V7 classification system as they pertain to staging of the primary tumor. 